NBER WORKING PAPER SERIES

\author{
THE RESPONSE OF WAGES AND \\ ACTUAL HOURS WORKED TO THE \\ REDUCTIONS OF STANDARD HOURS
}

Jennifer Hunt

Working Paper 5716

\author{
NATIONAL BUREAU OF ECONOMIC RESEARCH \\ 1050 Massachusetts Avenue \\ Cambridge, MA 02138 \\ August 1996
}

I thank Alison Booth, Michael Burda, Dan Hamermesh, Ed Lazear and Anne Beeson Royalty for detailed comments, and seminar participants at the Deutsches Institut für Wirtschaftsforschung, the Hoover Institution at Stanford, the Humboldt Universität zu Berlin and McMaster University (Conference on Employment Protection) for suggestions. Reinhard Bispinck provided me with essential information, and Tomas Rauberger was invaluable in setting up the data. This work was carried out while I was a National Fellow at the Hoover Institution. This paper is part of NBER's research program in Labor Studies. Any opinions expressed are those of the author and not those of the National Bureau of Economic Research.

(C) 1996 by Jennifer Hunt. All rights reserved. Short sections of text, not to exceed two paragraphs, may be quoted without explicit permission provided that full credit, including $(\mathcal{O}$ notice, is given to the source. 


\title{
THE RESPONSE OF WAGES AND \\ ACTUAL HOURS WORKED TO THE \\ REDUCTIONS OF STANDARD HOURS
}

\begin{abstract}
A transformation of what had become a universal 40 hour standard work week in Germany began in 1985 with reductions negotiated in the metal-working and printing sectors. These reductions have continued through 1995 , and were followed by reductions in other sectors. The union campaign aimed to increase employment through "work-sharing," and is being emulated in the United States with the launch of a reduced hours campaign by the AFL-CIO. Using data from the German Socio-Economic Panel, I find that increased overtime or reduced short time was little used to offset the reduction in standard hours: a one hour reduction in standard hours appears to have translated into a reduction in actual hours worked of between 0.85 and 1 hour for workers in manufacturing. One might expect this to have resulted in a loss of earnings for workers in affected industries. However, I substantiate the union claim of "full wage compensation": reductions in standard hours were accompanied by a relative rise in the hourly straight-time wage of $2-3 \%$ for each hour fall in standard hours, enough to keep monthly earnings the same as in unaffected industries.
\end{abstract}

Jennifer Hunt

Department of Economics

Yale University

PO Box 208264 Yale Station

New Haven, CT 06520

and NBER

hunt@econ.yale.edu 
From 1 April 1985 weekly working time was reduced to 38.5 hours with full wage compensation. [...] In 1987 the metalworking and printing industries were party to new agreements which reduced working time in two stages to 37 hours a week, with full wage compensation. [...]

In the event, thanks to the economic upswing that started in 1984, it was the wage restraints incorporated in the agreements that proved to be the more important concession.

Gerhard Bosch, German Confederation of Trade Unions (1990)

Many people believe that a reduction in hours worked per person would lead (or has led) to increased employment. Whether "work-sharing" is effective at a given wage is, however, theoretically ambiguous, and in addition to the scale effect, depends upon substitution effects between workers and other factors of production. In the United States the AFL-CIO has launched a campaign for a four-day 32-hour week, while reduced standard hours are also the preferred route to shorter actual hours in Europe. Yet with overtime a possibility, a reduction in the standard work week may lead to a less than one for one reduction in actual hours per week. Hence, the link between standard and actual hours is a key one for work-sharing. Furthermore, the response of wages to reductions in actual hours is critical. If the reduction in hours brings workers closer to their optimal hours, theory suggests they may be prepared to take a cut in hourly wages. In the European setting, however, unions have typically demanded an increase in hourly wages to compensate the lost hours, which would appear to make increases in employment less likely.

Standard hours were greatly reduced in (West) Germany beginning in 1985 . These reductions were initiated by trade unions, unlike in countries such as France, where reductions were mandated by the government. There appears to be a consensus that the reductions in standard hours translated approximately one for one into reductions in actual hours, although this 
has not been examined using micro-data. There is less consensus on the response of wages, however. On the one hand, unions claim to have achieved standard hours reduction with "full wage compensation", that is, no reduction in monthly pay, which suggests that hourly wages may have risen in affected industries relative to those with no standard hours reductions. On the other hand, observers including union observers suggest that standard hours reductions caused "wage restraint". These two possibilities may be reconciled if the hourly wage raises workers in the affected industries would have received in the absence of standard hours reductions were higher than the raise needed merely to compensate the lost hours. In this case, hourly wages could rise, but likely by less than in other industries.

Using data from the German Socio-Economic Panel for the period 1984-1989, I establish that for Arbeiter (workers paid hourly) in manufacturing, actual hours fell by $0.85-1$ hour in response to a one hour fall in standard hours. Evidence for services and Angestellten (salaried employees) is more difficult to analyze. At least for one class of workers there is thus indeed a large loss in hours to be compensated. I then examine wages, and find that workers in sectors achieving reductions in standard hours bargained sufficient increases in the straight-time hourly wage that their monthly pay did not fall relative to other workers. These results are inconsistent with the hypothesis that standard hours reductions caused wage restraint.

\section{Hours Reductions in Germany}

Unions in Germany bargain at the industry level, and conditions of union contracts apply not only to members, but to almost all other workers as well. Annual hours may be reduced either by increasing holiday time or by reducing standard weekly hours. By 1975 the prevailing 
conditions were 40 hours per week and 30 days annual leave, and by $198195 \%$ of workers had a standard working week of 40 hours ${ }^{1}$. The metal workers' union, IG Metall, which along with the printing union IG Druck had spearheaded earlier reductions in weekly hours, struck unsuccessfully in 1978-9 to reduce standard weekly hours below 40 . Other unions, such as IG Chemie, the chemical union, focused on reducing life-time hours by reducing the retirement age. IG Metall resumed its demands in 1982-3, and was successful after a protracted strike in early 1984. The declared aim of the hours reductions was a reduction in unemployment through work-sharing. Hours in the metal-working sector (employing almost four million workers) were reduced to 38.5 in 1985 .

A key element of the agreement, upon which agreements in many other sectors were modelled, was the concession to employers of greater flexibility in the use of standard hours. In particular, standard hours no longer had to be spread evenly over each day of the week, and could in fact vary from week to week as long as they averaged to the agreed number over a certain number of months. Also, standard hours could vary across employees as long as they averaged to the agreed number. It is important to note that the implementation of flexibility is a matter to be negotiated at the plant level between the management and the works council, and surveys have found that the majority of plants, particularly small plants, have not taken advantage of the flexibility provisions (Bosch et. al. 1988).

A further issue to be resolved by management and works councils is the method of implementation of the reduced standard week. Some firms reduced hours on Thursdays and Fridays, some reduced the hours of each weekday by an equal amount, while others reduced hours by awarding workers days off. Bosch (1990) reports that, initially, capital-intensive 
industries preferred days off, while labor intensive industries reduced weekly or daily hours. As the standard work week fell further, however, the number of days off to be allocated became too great to be efficient, and the move to a reduction in daily hours (or a mixture of reduction in hours and days off) became more generalized.

Finally, certain union agreements recommended caps on overtime (or the compensation of some overtime with days off) to prevent the substitution of overtime hours for standard hours. This is again something to be implemented at the plant level by the works council and management, and is obviously potentially important for work-sharing.

The agreement in the metal-working sector and the simultaneous agreement in the printing sector were followed by more and more manufacturing and service industries over the subsequent years. IG Metall itself in two later agreements negotiated further step-wise reductions in standard hours, which have recently culminated (October 1995) in the 35-hour week. IG Metall has announced that it seeks further reductions. Average standard hours worked fell from 40.0 in 1984 to 38.8 in 1989 to 37.7 in 1994 (IAB 1995). In 1990 actual annual hours per worker were $10 \%$ lower in Germany than in the U.S. (Bell and Freeman 1995). ${ }^{2}$

The agreements reached concerning standard hours often extend over a period of several years, involving step-wise falls in hours, while wages typically continue to be renegotiated each year. An important question is how the wages negotiated were influenced by standard hours reductions and flexibility concessions. In most cases the unions announced that they had achieved their aim of "full wage compensation", meaning that weekly or monthly earnings (without overtime) were not reduced despite the hours reductions (which implies a rise in the 
hourly straight-time wage). It is not clear how to measure the success of "full wage compensation", however. At a minimum it presumably means that nominal monthly earnings did not fall (and inflation was low in the 1980s). Real wages were rising steadily, however, and monthly earnings, and hence possibly hourly wages, might have fallen relative to those in sectors without falls in standard hours. Lehment (1991) notes that the period of standard hours reductions in the 1980s was a period of wage restraint (defined as the gap between nominal GDP growth and nominal wage growth) at the aggregate level, and notes that the standard hours reductions may have permitted this restraint. Stille and Zwiener (1988) believe based on earlier trends that monthly pay in industries reducing hours rose more slowly than would have otherwise been the case, but do not make a pronouncement regarding hourly wages.

\section{Theory}

Consider a firm taking standard hours $\left(\mathrm{h}_{\mathfrak{b}}\right)$, hourly wages $(w)$ and the rental rate of capital (r) as given, and choosing actual hours (h), employment $(\mathrm{N})$ and capital $(\mathrm{K})$ in the presence of fixed costs of employment (f), and an overtime premium (p):

$$
\max _{h, N, R} g(h, N, K)-w h N-f N-p w(h-h) N-r K
$$

Assume that this firm chooses non-zero overtime hours $\left(h>h_{3}\right)$. Consider now an exogenous reduction in standard hours, which due to the overtime premium increases labor costs. There will be a scale effect, tending to reduce employment and hours per week, and a substitution effect from labor services to capital. Substitution between hours and workers is made clearer by considering the marginal cost of hiring an additional worker $\left(\mathrm{MC}_{\mathrm{N}}\right)$ and the marginal cost of an additional hour's work by existing workers $\left(\mathrm{MC}_{\mathrm{b}}\right)$ : 


$$
\begin{aligned}
& M C_{N}=w h+f+p w\left(h-h_{s}\right) \\
& M C_{h}=(1+p) w N
\end{aligned}
$$

Clearly the marginal cost of additional overtime is unaffected by standard hours (and is determined only by the wage and the overtime premium), while the marginal cost of an additional worker is increased when standard hours are reduced, since more of this worker's wages must be paid at the overtime premium. Hence, the firm will substitute from workers to hours, an effect which obviously tends to decrease employment. Figure 1a shows the two marginal cost schedules for original standard hours $h_{b}{ }^{0}$ and reduced standard hours $h_{a}{ }^{1}$. This case is that of a firm originally having optimal hours such as h.. Employment will therefore fall, and the effect on weekly hours depends upon whether the scale effect and substitution from labor to capital dominates the substitution from workers to hours.

Figure 1a makes clear, however, that the original optimal hours (and the magnitude of the standard hours reduction) are critical for the response of the firm along the worker-hours margin. Consider a firm whose optimal hours are below even the new standard hours, at $h_{*}{ }^{b}$. If we assume that the law constrains hours to be at least standard hours, this firm will move its actual hours from the original kink point $h_{\mathbf{s}}{ }^{0}$ to the new kink point $h_{\mathbf{a}}{ }^{1}$. $\mathbf{M C}_{\mathrm{b}}$ has thus not changed, while $\mathrm{MC}_{\mathrm{N}}$ has fallen, and the firm will substitute from hours to workers, the opposite of the previous case. The scale effect and the capital-labor substitution effect will work to increase employment. The overall effect is that hours will fall, while employment will rise.

We could extend the analysis to cases permitting firms to work less than standard hours (since this is possible in Germany, albeit not on a permanent basis). If a firm's original hours are below both the new and old standard, as in h. ${ }^{\mathrm{b}}$ in Figure 1a, the fall in standard hours will 
not affect its behavior. If its original hours are above the new standard hours, workers-hours substitution will depend on all the magnitudes involved (while scale and capital-labor substitution effects will tend to lower employment and hours).

For the firm with original optimal hours h.', the response to a fall in standard hours is different if we allow the overtime premium to be a positive function of the number of overtime hours. Many German industry contracts specify a $25 \%$ premium for the first ten overtime hours per week or two overtime hours per day, and a higher premium thereafter. If the fall in standard hours means the firm's current hours are now in the higher premium zone, as in Figure $1 \mathrm{~b}$, the $\mathrm{MC}_{\mathrm{b}}$ may rise more than the $\mathrm{MC}_{\mathrm{N}}$, and the firm will substitute from hours to workers. The net effect on employment will be ambiguous, and hours will fall. ${ }^{3}$

These cases make clear that if employment is to rise, there must be a large substitution from hours to workers. The finding that actual hours fall a lot is a necessary condition for work-sharing to be effective, but it is not a sufficient condition, since actual hours may be falling due to the scale effect or substitution to capital. Substitution from hours to workers is more likely the closer substitutes hours per week and workers are in production. ${ }^{4}$ It is also more likely if many firms' optimal hours are below standard hours and they cannot use short-time to avoid being constrained to work standard hours. This suggests that the timing of the hours reduction in the business cycle could be important: standard hours reductions at business cycle troughs when optimal hours may be low compared to standard hours are more likely to lead to increased employment (or possibly stable employment if there are hoarded workers) and reduced actual hours. 
It is important to consider that other parameters might change in response to the reduction in standard hours. The overt concession in exchange for shorter standard hours on the part of German unions was the introduction of greater flexibility. Presumably flexibility has a positive scale effect, but it may be complementary with capital, and its effect on the trade-off between workers and hours must be examined in a more complex model.

Another consideration important for Germany is that the hourly (straight-time) wage bargained may have been influenced by the standard hours reductions. Calmfors (1985), Hoel (1987) and Houpis (1993) endogenize the wage in a model of work-sharing with a monopoly union. If the reduction in hours brings hours closer to the workers' optimum, the value of the additional leisure may allow the wage to fall, although the result is ambiguous. (Forces working to raise the hourly wage include the fact that lower monthly income reduces the disutility of unemployment.) A wage decrease would cause a substitution from workers to hours due to the fixed cost of hiring a worker. $^{5}$ The net effect on hours is therefore positive, and on employment is ambiguous, although we would usually expect the scale effect and substitution from capital to predominate and raise employment. We have seen, however, that the German union claim to have accomplished full wage compensation suggests a rise in the straight-time hourly wage.

Finally, it is possible that individuals are more productive when they work fewer hours. Lower actual hours thus induce capital-saving technological progress. This has an ambiguous effect on the already ambiguous employment response, but should lead to a larger fall (or lower rise) in actual hours. 
This section has considered only the effects of a reduction in working hours, not the causes - for a general analysis of union choice of hours, see Earle and Pencavel (1990). Bell and Freeman (1995) examine the issue of why Germans want to work less than Americans.

\section{Previous Empirical Work}

A number of papers use aggregate manufacturing times series data to look at the effect of standard hours on actual hours and employment, including Franz and König (1986), who examine Germany from 1964-84, an earlier period of reduction in standard hours. They report that a $1 \%$ reduction in standard hours both reduces a worker's total hours by $0.99 \%$ and increases a worker's overtime by $0.4 \%$. Hart and Sharot (1978) and de Regt (1988) find that a $1 \%$ reduction in standard hours reduces actual hours by $0.92 \%$ for the UK in the period 1961 72 , and by $0.89 \%$ for the Netherlands in the period $1954-82$, respectively (see also Hamermesh 1993). Brunello (1989), examining Japan in the period 1973-86, finds a different result: that reducing standard hours has essentially no effect on actual hours. These papers, as well as Wadhwani (1987) and Faini and Schiantarelli (1985), find that a $1 \%$ reduction in standard hours raises employment by $0.2-1.0 \%$.

Hart (1987) uses pooled data for 25 German industries for $1969-81$ and finds that a $1 \%$ reduction in standard hours reduces actual hours (corrected for short time) by $1.2 \%$ (significantly different from one), contrary to theory. The variation in standard hours in this pooled specification comes from both the cross-section and time-series. The only paper to examine these issues using micro-data is Hart and Wilson (1988), which uses British firm-level data pooled for the period 1978-82. The drawback of this paper is that the variation in standard 
hours appears to come in the cross-section rather than time-series dimension. They find that a one hour reduction in standard hours reduces actual hours by 0.77 hours. Neither of these papers finds a significant effect of standard hours on employment.

Stille and Zwiener (1987) attempt to tease out the effects of the 1985 standard hours reduction in the metal-working sector by examining aggregate trends in actual hours, overtime, short time and employment for that sector. They judge that weekly overtime per person was about one hour higher in the years following the standard hours reduction of 1.5 hours, and guess that perhaps half of the increase in overtime was due to the cyclical upswing, and half due to reductions in standard hours. They believe that the reduction in short time was unaffected by reductions in standard hours, and influenced only by the business cycle. Their employment figures imply an elasticity of employment with respect to standard hours of about -0.5 , which lies between the elasticities found by the employers' association and the union.

Three papers address numerically the question of wages and hours reductions in Germany. Macro-simulations in Stille (1995) suggest unit labor costs were lower in the period 1982-92 than they would have been in the absence of standard hours reductions. Franz and Smolny (1994) address this issue (amongst others) in a macro time-series model using quarterly data for German manufacturing from 1970-1989. They find that in certain industries hourly wages rose in response to falls in standard hours. Finally, Lehment (1991) finds that, when wage restraint is controlled for, reductions in standard hours are insignificant in aggregate time series modelling employment growth for 1973-90. Manufacturing time series for Sweden (Holmlund and Pencavel 1988) and Norway (Nymoen 1989) suggest that hourly wages rise when standard hours fall. 
In a paper closely related to mine, Trejo (1991) examines the effect of the mandated overtime premium in the United States on hours worked and wages. Notice that the effects of increasing the overtime premium may be cancelled out by reducing the straight-time wage, so that the effect of the overtime premium may appear exclusively in wages. (The equivalent for a reduction in standard hours is a reduction in the fixed cost of employment.) He finds evidence that the wage does adjust partially to offset an increase in the overtime premium, but that the offset is not complete, so that effects appear in other variables such as hours worked.

\section{Data}

The data used are from the German Socio-Economic Panel for the years 1984-1989. The variables of most interest here are the answers to the questions about hours on the current job (after the first survey, the questionnaire specifies that if the respondent has more than one job, that $s$ /he should refer to the main job). The questions asked every year are: "What are your collectively bargained weekly work hours without overtime?", and "What is on average your actual work time including any overtime [hours per week]?". ${ }^{6}$ Some information about the worker's firm is known: the industry (35 categories) and firm size (four categories). Except in 1987, workers were asked about the compensation for overtime: whether they are paid, receive days off, a mixture of the two, or whether they are not compensated (or do not work overtime).

In 1986,1988 and 1989 the hours questions were followed by the question: "In the last month: did you work overtime, and if so, how much [hours]?". Notice that in addition to asking about monthly rather than weekly hours, this question specifically asks about the previous month, rather than about what happens on average. 
The survey does ask about short-time, and bad weather work interruptions for construction workers, but unfortunately only about the number of weeks of short-time or bad weather compensation received in the previous year. Some respondents recorded actual work time below standard (agreed) work time, but only a minority of them reported having received short-time or bad weather compensation in the following year's survey. The rest may be due either to measurement error in either the hours variables or in short-time, may reflect reduced hours due to illness or other cause (despite the fact that the question asks about the average week), or may indicate uncompensated hours lost due to short-time work.

The fact that some workers receive their standard hours reduction or overtime compensation in the form of days off would not matter if they accurately reported actual hours from, for example, the survey week. Those workers with their days off in that week would average with those working more than standard hours in that week. Unfortunately, the question about actual hours refers to an "average" week, while the question about "last month" specifies overtime, rather than actual hours, and will obviously not elicit negative responses. Since workers may not think of a week with days off as an average week and since monthly overtime cannot be negative, it is possible that both reported actual hours and actual hours calculated as standard hours plus reported overtime are overestimates. If the trend is towards more compensation with days off for those with falling standard hours, my result will be biased toward finding a shift to overtime and increased actual hours. If the use of days off follows a more complicated pattern over time, the effect is unclear. Many firms have introduced flexitime for Angestellten, who in some cases may choose to work more for a period in order to bank days off. Similar issues may apply in this case. ${ }^{7}$ 
It would be helpful if one could learn from the GSOEP about standard annual hours, rather than weekly hours. This would circumvent some of the ambiguity in the response to the questions about weekly hours, and is also in a sense more the variable of interest. However, there is no good measure of annual standard or actual hours.

The wage variable used is earnings on main job in the previous month, without bonuses (common bonuses are thirteenth month salary, holiday money etc). The only other wage information available concerns total monthly earnings in the previous year.

I wish to focus on full-time workers, and hence drop respondents who said they had less than 35 standard hours. I also drop workers who said their standard hours were greater than 45 , to remove the most obvious outliers (standard hours for all included industries were 40 or less throughout the sample period). I drop workers in fishing, agriculture, or private households, and the self-employed, for whom standard hours are not well-defined. I drop workers aged 55 or over, since during the period under consideration special agreements were reached in some industries to reduce the hours of older workers below those of others in the same industry or to allow early retirement. I also drop those doing apprenticeships and those under age 20, although they could arguably be included. Finally, I drop those with missing actual or standard (agreed) hours, industry, firm size, job type (self-employed, salaried etc) or education.

Published standard hours by industry are obtained from tables supplied by the WSI (Wirtschafts- und Sozialwissenschaftlichen Instituts des Deutschen Gewerkschaftbundes) (HansBöckler-Stiftung 1995). Data on industry-level sales are obtained from the Statistisches Bundesamt, and are deflated with the producer price index. 
Hours and Overtime Compensation in the GSOEP Data

A first check is made by comparing two measures of overtime from the GSOEP data with published data for non-self-employed full-time workers (IAB 1994). For the purposes of this comparison the sample differs from that used in the rest of the paper: only the self-employed, and those with standard hours below 35 or above 45 are excluded. Figure 2 compares weekly overtime from the IAB statistics, mean reported overtime last month divided by 4.33 , and the mean of actual hours minus standard hours (with negative values changed to zeros). The sample weights are used in calculating the means. For the three years it is available, the measure based on monthly overtime tallies remarkably well with the published data, while the measure based on actual hours is higher, and fluctuates differently. (Notice that the flat aggregate overtime plot masks considerable fluctuations at the industry level.) This figure suggests that the monthly overtime figures should be preferred. A similar exercise may be performed for the measure of average "undertime" (standard minus actual hours, with negative values changed to zero), and this average is considerably higher than the sum of published short-time and bad-weather time (these results are not shown).

Figure 3 shows the dramatic transformation in standard and actual hours for Arbeiter (loosely: workers paid hourly) in manufacturing and construction in the sample, between 1984 and $1989 . .^{8}$ In 1984 standard hours were almost universally 40 per week, while only about half still had 40 hours in 1989. Actual hours also have a huge shift down from 40 hours. Figure 4 shows a similar pattern for Angestellten (salaried workers) in manufacturing and construction. Figures 5 and 6 show that the transformation in services was less advanced by 1989 than in manufacturing. 
Figures 7 and 8 show how overtime is compensated for Arbeiter and Angestellten in manufacturing/construction and in services in 1984 and 1989. A large but falling majority of Arbeiter in manufacturing are (only) paid for overtime, while about only about half of Arbeiter in services receive compensation exclusively in the form of monetary payment. Only a minority of Angestellten are only paid, and the proportion fell between 1984 and 1989.

Figures 9 and 10 show the distribution of overtime as measured by the difference between actual and standard weekly hours. $23 \%$ of Arbeiter in manufacturing worked overtime in 1984 and $33 \%$ in 1989 , and slightly lower proportions in services. $4 \%$ of Arbeiter in manufacturing report undertime in 1984, and 3\% in 1989. A very high proportion of Angestellten report overtime. Figure 11 shows for 1989 overtime as measured by the response to the question about overtime in the last month. For comparison purposes the variable is divided by 4.33 to obtain weekly overtime. This measure suggests approximately the same proportions working overtime, but indicates less overtime per week (it is not clear if this was to be expected, given that the weekly question asked about the "average" week).

Such a large proportion of Angestellten get payment in days off that the overtime figures are likely to be very unreliable, so I emphasize Arbeiter in my hours analysis. I retain Arbeiter in services, even though almost half of those doing overtime receive some compensation in the form of days off. Notice that even though a small proportion of Arbeiter in manufacturing are compensated for overtime with days off, the proportion is rising, which will introduce a bias towards finding a shift to overtime if the rise is occurring principally in industries whose standard hours were reduced. Beamten (civil servants) are also excluded, although others in the public sector are retained. 


\section{Hours Results}

My interest is not in the relation between the level of standard hours and the level of actual hours: I want to know how actual hours change when standard hours change. If construction always has high standard hours and high overtime for technological reasons, I do not want this cross-section component to lead me to conclude that raising standard hours will raise overtime, and hence raise actual hours more than proportionately, for example. A common way to look at the relation between differences with panel data is to use individual fixed or random effects. If I do this, with actual hours as the dependent variable and standard hours and possibly industry dummies as an independent variables, I still allow the variation in standard hours arising from a worker's change of industry to influence the coefficient on standard hours. To restrict the variation in standard hours to be within job variation, and hence primarily variation induced by the union contracts, I use information on job changes to generate workerjob fixed or random effects. That is, each employment spell with the same firm receives a fixed or random effect. (Some workers will experience hours changes by changing jobs within a firm: this variation will be allowed to influence the coefficient on standard hours.)

Results were generally found to differ quite a bit between manufacturing and construction, on the one hand, and services on the other, so analysis is conducted separately for the two sectors. The first set of results, for manufacturing and construction, is shown in Table 1 , where the dependent variable is actual hours worked on average in a week, and the main independent variable of interest is "agreed" or standard hours per week as reported by the respondent. A coefficient of 1 on standard hours implies no shifting to overtime, while a 
coefficient of 0 implies full shifting to overtime. The regressions include year dummies, which control partially for the business cycle and for other trends in overtime.

The first two columns perform fixed and random effects, and the coefficient on standard hours in the preferred fixed effects specification is 0.85 and significantly different from 1 . As was discussed above, the use of days off as compensation for overtime when standard hours are reduced is likely to bias the coefficient towards zero. Also, classical measurement error in standard hours will bias the coefficient toward zero. This latter problem may be remedied by instrumenting standard hours as reported by the respondent with standard hours for the industry in the month of the interview as obtained from published sources. ${ }^{9}$ Because the GSOEP aggregates industries, the published hours used to instrument are an average (weighted by employment) of standard hours in the sub-industries. The third (FE IV) column in Table 1 does this for fixed effects. The point estimate of the coefficient on standard hours rises to 1.16 , but the standard error is very large (although the coefficient is significantly different from zero). ${ }^{10}$ Another possible instrument for reported standard hours is the average response of respondents in the same industry and year. In the case of manufacturing this instrument seems to be correlated with the error term, and is not used.

The remaining columns of Table 2 analyze directly the incidence and length of overtime and undertime. The fourth column - $\mathrm{P}(\mathrm{OT}>0)$ - uses a fixed effects conditional logit to examine the probability of a respondent reporting actual hours greater than standard hours. The coefficient on standard hours is significant and negative, indicating a shift towards overtime use when standard hours are reduced. The magnitude of the coefficient implies that a $1 \%$ fall in standard hours raises the probability of overtime by $7.1 \% .^{11}$ The column headed "OT" 
indicates that standard hours do not significantly affect the length of overtime, conditional on overtime being positive. The coefficient of 0.28 in the $P(U T>0)$ column implies that a $1 \%$ reduction in standard hours would reduce the incidence of probability of reported actual hours being lower than standard hours by $11 \%$. (In regressions not reported, the length of undertime conditional on undertime being non-zero was not significantly affected by standard hours. Nor did regressions including undertime as negative values of overtime yield significant coefficients.)

The response of overtime and undertime to a one hour fall in standard hours may be calculated from the logit elasticities. A reduction in standard hours from 40 to 39 hours is a $2.5 \%$ fall, which implies an increase in overtime of 0.3 hours (average overtime is 1.75 hours) and a reduction in undertime of 0.2 hours (average undertime is 0.75 hours), meaning that actual hours only fall by 0.5 hours. The lower response of actual hours implied here compared with the regressions with actual hours as a dependent variable is puzzling. It may be due to imprecise estimate of the effect of standard hours on the length of overtime and undertime. Length of overtime may have fallen, offsetting the impact of the increased incidence, but this would require quite a large coefficient compared to the standard error as currently estimated in the final column.

Table 2 repeats the regressions of Table 1 for the service sector. The coefficient on standard hours in the fixed effects specification is 0.62 , lower than for manufacturing, and possibly due to greater measurement error (as inspection of the data suggests). The third column of Table 2 instruments standard hours with the average response of similar respondents in the same year. The correlation is 0.3 , and for services correlation of this instrument with the errors may be rejected. Again the main effect of instrumenting is to increase the standard error. The 
problem with this instrument may be that the large number of service categories means some have very few workers in them in a given year, and hence averaging does not reduce measurement error much. ${ }^{12}$ The coefficient on standard hours in the regressions examining overtime and undertime directly are insignificant, although in the overtime logit it is close to significant.

So far the only control for the business cycle used has been year dummies, which is rather crude since different industries fluctuate differently. It could be that industries which reduced hours experienced falls in demand and hence desired in any case to reduce overtime hours. In the absence of information truly reflecting demand for the output of sectors, the best that can be done is to control for sales, while realizing that this to a large extent conditions out the scale effect. However, sales in either the month or year of the interview was always insignificant, whether entered directly or interacted with standard hours. Replacing sales with month-to-month or year-to-year log difference in sales makes no difference.

Table 3 investigates whether the effect of standard hours on actual hours varies by firm size. Many of the contracts reducing standard hours provided for increased flexibility in the use of standard hours, which, although a concession by the unions, was thought likely to work towards higher employment by reducing the scale effect and possibly the substitution from labor to capital by making labor more attractive along another dimension. It was generally thought that the flexibility clauses, implemented on a firm by firm basis, could only be taken advantage of by large firms. The results, while not always significant, suggest less shifting towards overtime in the excluded category: firms with more than 2000 employees, although the magnitudes are not large. 
The results of these tables may be checked by using the responses to the direct question about monthly overtime. A second measure of actual weekly hours is constructed by adding standard hours and reported overtime hours in the previous month divided by 4.33 . The bias on the uninstrumented coefficient on standard hours in this case is unclear - classical measurement error in this case biases the coefficient toward one, since the measurement error is also added to the independent variable. However, the fact that the overtime variable has no negative responses may introduce a bias toward zero as discussed above. Table 4 presents results for manufacturing of regressions run for the years 1986, 1988 and 1989, the years for which monthly overtime is available. The top panel of the table reruns the regressions of Table 1 using reported actual hours for the subset of years, as a basis for comparison, while the lower panel reports results for these regressions using the actual hours variable constructed from monthly overtime. The results of the top panel are similar to those found for all six years in Table 1, although standard errors are larger.

The uninstrumented fixed and random effects results in the lower panel indicate coefficients very close to one, possibly due to the upward bias of the classical measurement error (although these coefficients are not significantly different from those in the upper panel). Instrumenting in the following column scarcely lowers the point estimate, and the large standard error means it is still not significantly different from one. The fixed effect conditional logit for the probability of reporting overtime yields an insignificant coefficient on standard hours, and likewise for fixed or random effects estimation of the length of overtime (conditional on overtime being positive) in the final column. Thus the results of this panel do not point to any shift to overtime, unlike the results of Table 1. 
Table 5 repeats these regressions for services. The number of observations is rather small in these regressions (the fixed effects regressions are in effect based on the 329 personjobs which have more than one observation), so the standard errors are large enough in both panels so that little can be inferred. The point estimates in the lower panel again point to no shifting towards overtime. Interacting standard hours with the firm size dummies in the regressions based on reported monthly overtime yield insignificant coefficients.

The analysis has yielded qualitatively different results for manufacturing depending upon whether it was based on reported actual hours, which indicated shifting to overtime and from undertime, or reported overtime in the previous month, which showed no shifting, but quantitatively the difference is not large: a one hour reduction in standard hours reduces actual hours by between 0.85 and 1 hour. There is one other set of variables to be appealed to, namely the information on receipt of short-time or bad-weather compensation. Fixed effects conditional logits have been run for the probability of reporting such compensation, and the coefficient on standard hours in these regressions is insignificant (these results are not shown).

The results for Angestellten are not reported, as the hours variables are considered too unreliable, but the results are summarized here. For manufacturing the fixed and random effects regressions suggest more shifting towards overtime than for Arbeiter, when analysis is based on reported actual hours. Otherwise results are similar to those for Arbeiter, including that instrumenting principally raises standard errors, that fixed and random effects regressions for constructed actual hours yield coefficients on standard hours close to one, and that fixed effects conditional logits for the probability of reported monthly overtime yield insignificant coefficients on standard hours. 


\section{Wage Results}

Were a measure of hourly straight-time wage available, the approach would simply be to add standard hours as a regressor to fixed and random effects (person-job effects) wage regressions. This approach does oversimplify the problem: while in some years standard hours are predetermined and only wages are endogenous, in many years wages and hours are jointly determined, and furthermore there may be timing issues involved, such as the wage bargaining anticipating future reductions in standard hours. Nevertheless, such an approach will pick up the broad correlation between changes in wages and changes in standard hours even if causality is not implied and fine details of timing are overlooked.

The difficulty addressed here is therefore simply that the wage measure available is monthly and includes possible overtime $\left(\mathrm{OT}_{\mathrm{M}}\right)$ and undertime $\left(\mathrm{UT}_{\mathrm{M}}\right)$. Denote $\mathrm{w}$ as the straighttime hourly wage, and $w_{M}$ as the monthly wage including overtime and undertime. $p$ is the overtime premium, $h_{s}$ is the weekly standard hours. The straight-time hourly wage is modelled as

$$
\log (w)-\alpha+\beta X+\gamma h_{s}+e
$$

(with $i, t$ subscripts and modelling of the error suppressed for simplicity), while the monthly wage is defined as

$$
w_{M}=w\left(4.33 h_{s}+(1+p) O T_{M}-U T_{M}\right)
$$

The log of the monthly wage may thus be written

$$
\begin{aligned}
\log \left(w_{M}\right) & -\alpha+\beta X+\gamma h_{s}+\epsilon+\log \left(4.33 h_{s}+(1+p) O T_{M}-U T_{M}\right) \\
& -\alpha+\beta X+\gamma h_{s}+\epsilon+\log \left(4.33 h_{s}\right)+\log \left(1+\frac{(1+p) O T_{M}}{4.33 h_{s}}-\frac{U T_{M}}{4.33 h_{s}}\right) \\
& -\alpha^{\prime}+\beta X+\gamma h_{s}+\log \left(h_{s}\right)+\frac{1+p}{4.33} \frac{O T_{\underline{M}}}{h_{s}}-\frac{1}{4.33} \frac{U T_{M}}{h_{s}}+\epsilon
\end{aligned}
$$


where the approximation $\log (1+\mathrm{x})=\mathrm{x}$ for small $\mathrm{x}$ has been used, which assumes that monthly overtime and undertime are small compared with monthly standard hours.

The coefficient of interest is of course gamma. We have not yet finished with data difficulties, however. We know monthly overtime for certain years, but we do not have a corresponding measure of monthly undertime. One possibility is to estimate equation (5) without the term for undertime, hoping that its omission does not bias gamma. A second possibility is to use the weekly measures of overtime and undertime (based on reported actual hours) and assume that multiplying by 4.33 yields monthly overtime and undertime (which is likely to overstate both).

The coefficients on $\log \left(\mathrm{h}_{\mathrm{s}}\right)$ and (where included) $U T / \mathrm{h}_{\mathrm{s}}$ are restricted to be 1 and -1 respectively. Initially the coefficient on $\mathrm{OT} / \mathrm{h}_{\mathrm{s}}$ was left unrestricted, since $\mathrm{p}$ varies across people: if overtime is compensated it is typically at $25 \%$ premium, but Sunday work, for example, carries a higher premium, and for Angestellten some overtime is not compensated. However, the unrestricted coefficient estimated implied an overtime premium of only about $12 \%$, while respondents to the question asked in 1986 about their overtime premium gave a median response of $25 \%$ (for both Arbeiter and Angestellten; the means were $24 \%$ and $21 \%$ respectively). In the results presented, therefore, $\mathrm{p}$ is restricted to be 0.25 , but this restriction hardly affects gamma.

Table 6 presents results using the monthly measure of overtime, omitting any measure of undertime. There are fewer observations than in the corresponding regressions in the hours section due to missing values in the wage variable. The results for fixed effects are presented random effects produced extremely similar coefficients on standard hours, and were rejected 
by the Hausman tests. The results show that a one hour fall in standard hours was associated with a significant relative rise in the straight-time hourly wage of between $2 \%$ and $3 \%$, except for Angestellten in services, where the coefficient is negative but insignificant.

Table 7, where overtime and undertime are based on reported actual hours, show significant negative coefficients on standard hours only for Arbeiter in manufacturing and Angestellten in services. Imposing a coefficient of -1 on the undertime ratio variable has an important effect on the coefficient on standard hours: when the overtime and undertime ratio variables are left unrestricted, the undertime ratio is insignificant, and the coefficients and standard errors on standard hours are very similar to those in Table 6. Undertime therefore does not seem to capture what was intended, and the results of Table 6 are preferred.

As usual, measurement error in standard hours will bias its coefficient toward zero. The result of instrumenting with the instruments of the hours section is once again principally to increase the standard errors of the coefficient, so these results are not reported.

These results agree with those found by the time-series of Franz and Smolny (1994), and accord with the claims of the unions. A one hour fall in standard hours from 39 or 38 hours represents a $2.6 \%$ fall, while Table 6 suggests straight-time hourly wages rose $2-3 \%$. So monthly pay for an individual not working overtime remained the same after a reduction in hours, compared to individuals in industries with constant hours. Results not reported provide further support: log monthly wages are regressed on standard hours and year dummies for 198489 , without attempting to adjust for hours and overtime. As expected, the coefficients on standard hours are small (between -0.001 and 0.003 ) and insignificant, indicating that monthly pay was little affected by standard hours. 
To square these wage results with Lehment (1991), it must be the case that wage rises induce such a large substitution effect from workers to hours as to raise employment, and that this was of more importance than the reduction in standard hours. Another possibility is that the wage restraint he observed was not driven by standard hours reductions, but rather occurred in all industries. A final possibility, impossible to test without good data on capital, is that the reductions in standard hours raised productivity, so that effective wages fell.

\section{Conclusions}

Unions in certain German industries negotiated reductions in standard hours beginning in 1985 . Such reductions are likely to cause a negative scale effect and substitution towards capital, but employment may rise if there is sufficient substitution from hours to workers. I have established that, at least for Arbeiter (hourly workers) in manufacturing, a one hour fall in standard hours led to a fall in actual hours of between 0.85 and 1 hour. A large response such as this is a necessary condition for substitution from hours to workers to be large. These results are similar to results for other countries or time periods. The wording of the questions on hours worked make conclusions on substitution between workers and hours for Arbeiter in services and Angestellten (salaried workers) difficult.

Given that actual hours fell a lot, one would expect workers to experience a fall in earnings. I find in addition, however, that a one hour reduction in standard hours was associated with a $2-3 \%$ increase in the straight-time hourly wage, relative to sectors with no standard hours reduction. This hourly increase is enough to offset the fall in hours worked, substantiating the union claim that standard hours reductions were achieved with "full wage compensation". 
These results are incompatible with the notion that reductions in standard hours were accompanied by "wage restraint".

Strictly speaking, the effect of a wage increase on employment is ambiguous, as the presence of fixed costs of employment induces a substitution from hours to workers. The finding of higher wages is thus consistent with the finding of a large fall in actual hours. We do generally expect the scale effect and substitution to capital to predominate and reduce employment, however. Examination of wages and actual hours hence does not lead to unambiguous prediction of the net effect on employment of reducing standard hours. 
References

Bell, Linda and Richard Freeman. 1995. "Why Do Americans and Germans Work Different Hours?". In Friedrich Buttler et. al. eds. Institutional Frameworks and Labor Market Performance: Comparative views on the U.S. and German Economies Ruttledge, New York.

Booth, Alison and Martin Ravallion. 1993. "Employment and Length of the Working Week in a Unionized Economy in which Hours of Work Influence Productivity." Economic Record pp.428-436.

Booth, Alison and Fabio Schiantarelli. 1987. "The Employment Effects of a Shorter Working Week". Economica pp. 237-248.

Bosch, Gerhard. 1990. "From 40 to 35 hours: Reduction and flexibilisation of the working week in the Federal Republic of Germany". International Labour Review pp.611-627.

Bosch, Gerhard et. al. 1988. Arbeitszeitverkürzung im Betrieb: Die Umsetzung der 38.5-StundenWoche in der Metall-, Druck- und Holzindustrie sowie im Einzelhandel Köln.

Bosch, Gerhard and Steffen Lehndorff. (n.d.) "Annual Working Hours in Germany". Institut für Arbeit und Technik mimeo.

Brunello, Giorgio. 1989. "The Employment Effects of Shorter Working Hours: An Application to Japanese Data." Economica pp. 473-86.

Calmfors, Lars. 1985. "Work Sharing, Employment and Wages." European Economic Review pp. 293-309.

deRegt, Erik. 1988. "Labor Demand and Standard Working Time in Dutch Manufacturing, 1954-1982." In Robert Hart ed. Employment, Unemployment and Labor Utilization Unwin Hyman, Boston.

Earle, John, and John Pencavel. 1990. "Hours of Work and Trade Unionism". Journal of Labor Economics pp.S150-174.

European Industrial Relations Review various issues.

Faini, Riccardo and Fabio Schiantarelli. 1985. "A Unified Frame for Firms' Decisions: Theoretical Analysis and Empirical Application to Italy, 1970-1980." In Daniel Weiserbs, ed., International Studies in Economics and Econometrics. Amsterdam: Martinus Nijhoff. 
Franz, Wolfgang and Heinz König. 1986. "The Nature and Causes of Unemployment in the Federal Republic of Germany since the 1970s: An Empirical Investigation. " Economica pp. S219-S244.

Franz, Wolfgang and Werner Smolny. 1994. "Sectoral Wage and Price Formation and Working Time in Germany: An Econometric Analysis." Zeitschrift für Wirtschafts- und Sozialwissenschaften.

Freeman, Richard. 1995. "Work-Sharing to Full Employment: Serious Option or Populist Fallacy?". Harvard University mimeo.

Hamermesh, Daniel. 1993. Labor Demand. Princeton University Press.

Hamermesh, Daniel. 1995. "The Demand for Workers, Hours and Days". University of Texas mimeo.

Hans-Böckler-Stiftung des Deutschen Gewerkschaftbundes. 1995. WSI-Informationen zur Tarifpolitik: Arbeitszeitkalendar West und Ost 1995. Düsseldorf.

Hart, Robert. 1987. Working Time and Employment Allen and Unwin, Boston.

Hart, Robert and T Sharot. 1978. "The Short-Run Demand for Workers and Hours: A Recursive Model." Review of Economic Studies pp.299-309.

Hart, Robert and Nicholas Wilson. 1988. "The Demand for Workers and Hours: Micro Evidence from the UK Metal Working Industry." In Robert Hart ed. Employment, Unemployment and Labor Utilization Unwin Hyman, Boston.

Hoel, Michael. 1987. "Can Shorter Working Time Reduce Unemployment?" In C.H. Siven, ed. Unemployment in Europe: Analysis and Policy Issues Timbro, Stockholm.

Holmlund, Bertil and John Pencavel. 1988. "The Determination of Wages, Employment, and Work Hours in an Economy with Centralised Wage-Setting: Sweden, 1950-83." Economic Journal pp.1105-1126.

Houpis, George. 1993. "The Effect of Lower Hours of Work on Wages and Employment." Centre for Economic Performance, LSE mimeo.

Institut für Arbeitsmarkt- und Berufsforschung (IAB). Various tables.

König, Heinz and Winfried Pohlmeier. 1988. "A Dynamic Model of Labor Utilization." In Robert Hart ed. Employment, Unemployment and Labor Utilization Unwin Hyman, Boston. 
Lehment, Harmen. 1991. "Lohnzurückhaltung, Arbeitszeitverkürzung und Beschäftigung. Eine empirische Untersuching für die Bundesrepublik Deutschland 1973-1990." Die Weltwirtschaft pp.72-85.

Nymoen, Ragnar. 1989. "Wages and the Length of the Working Day. An Empirical Test Based on Norwegian Quarterly Manufacturing Data." Scandinavian Journal of Economics pp.599-612.

Stille, Frank. 1995. "Wage Flexibility in Germany: The Case of Reducing and Flexibilising Hours of Work". Deutsches Institut für Wirtschaftsforschung mimeo.

Stille, Frank and Rudolf Zwiener. 1987. "Beschäftigungswirkungen der Arbeitszeitverkürzung von 1985 in der Metallindustrie." Deutsches Institut für Wirtschaftsforschung Wochenbericht pp. 273-279.

Stille, Frank and Rudolf Zwiener. 1988. "Arbeitszeitverkürzung als Instrument der Beschäftigungspolitik." WSI-Mitteilungen pp.590-598.

Trejo, Stephen. 1991. "The Effects of Overtime Pay Regulation on Worker Compensation." American Economic Review pp.719-740.

Wadhwani, Sushil. 1987. "The Effects of Inflation and Real Wages on Employment." Economica pp.21-40.

WSI-Mitteilungen Zeitschrift des Wirtschafts- und Sozialwissenschaftlichen Instituts des Deutschen Gewerkschaftbundes GmbH. Various issues. Bund Verlag, Köln. 
Notes

1. European Industrial Relations Review November 1983.

2. A large literature documents the implementation of standard hours reductions. See, for example, Bosch (1990), Bosch et. al. (1988), Bosch and Lehndorff (n.d.), European Industrial Relations Review (various issues), Stille (1995), WSI-Mitteilungen (various issues).

3. For theoretical examinations of work-sharing, see Booth and Ravallion (1993), Booth and Schiantarelli (1987), Calmfors (1985), Freeman (1995), Hart (1987), and König and Pohlmeier (1988).

4. See Hamermesh (1993) and Hamermesh (1995) for discussions of this.

5. To see this, write the ratio of the marginal costs, and take the derivative of this with respect to the wage:

$$
\frac{\partial \frac{M C_{N}}{M C_{h}}}{\partial w}-\frac{1}{(1+p)^{2} w^{2} N^{2}}\left(\left[h+p\left(h-h_{s}\right)\right](1+p) w N-\left[w h+f+p w\left(h-h_{s}\right)\right](1+p) N\right)
$$

This is less than zero if $\mathbf{f}>0$.

6. In the original: "Wie viele Wochenstunden beträgt Thre vereinbarte Arbeitszeit ohne Überstunden?" "Und wieviel beträgt im Durchschnitt Ihre tatsächliche Arbeitszeit einschliesslich eventueller Überstunden? [Stunden pro Woche]"

7. It is also unclear what workers who are on strike respond to the questions.

8. The sample weights are used to create the figures. The GSOEP oversamples foreigners, who work less overtime than Germans.

9. For the minority of workers in industries where bargaining does not take place at the national level, a weighted average of the standard hours in different regions is used.

10. The correlation between the published and reported standard hours is only 0.52 . Reasons for differences in addition to measurement error in the respondent variable include: the fact that in some industries standard hours only have to average to the agreed standard hours across employees, that I have imputed some interview months, that the aggregation of industries in the GSOEP means published hours is a weighted average of sometimes different standard hours, and that there is considerable noise in the GSOEP industry variable.

11. The elasticity representing the effect of $h$, on $P(O T>0)$ is calculated from

$$
\frac{\partial \log \overline{P(O T>0 ; X)}}{\partial \log h_{s}}-\beta_{h_{s}} \bar{h}_{s}[1-\overline{P(O T>0 ; X)}]
$$

12. The alternative obviously is to instrument as for manufacturing with published standard hours. The difficulty is that the bargaining units in services are much smaller, and have a greater tendency to bargain separately by region. 
Table 1: Analysis Based on Reported Actual Hours:

Manufacturing and Construction 1984-1989

(Standard Errors in Parentheses)

\begin{tabular}{|c|c|c|c|c|c|c|}
\hline & \multicolumn{3}{|c|}{ Reported actual hours } & \multirow{2}{*}{$\begin{array}{c}\mathrm{P}(\mathrm{OT}>0) \\
\text { FE logit }\end{array}$} & \multirow{2}{*}{$\frac{\mathrm{P}(\mathrm{UT}>0)}{\text { FE logit }}$} & \multirow{2}{*}{$\frac{\mathrm{OT}}{\mathrm{RE}}$} \\
\hline & RE & FE & FE IV & & & \\
\hline Standard Hours $h_{s}$ & $\begin{array}{c}0.96 \\
(0.06)\end{array}$ & $\begin{array}{c}0.85 \\
(0.09)\end{array}$ & $\begin{array}{c}1.16 \\
(0.31)\end{array}$ & $\begin{array}{l}-0.25 \\
(0.04)\end{array}$ & $\begin{array}{c}0.28 \\
(0.09)\end{array}$ & $\begin{array}{c}0.15 \\
(0.10)\end{array}$ \\
\hline Apprenticeship? & $\begin{array}{c}0.42 \\
(0.19)\end{array}$ & -- & -- & -- & -- & $\begin{array}{c}0.20 \\
(0.31)\end{array}$ \\
\hline University? & $\begin{array}{l}-0.10 \\
(1.02) \\
\end{array}$ & -- & -- & -- & - & $\begin{array}{l}-1.56 \\
(1.39) \\
\end{array}$ \\
\hline Foreign? & $\begin{array}{l}-0.65 \\
(0.18)\end{array}$ & -- & -- & -- & -- & $\begin{array}{c}0.63 \\
(0.28)\end{array}$ \\
\hline Female? & $\begin{array}{l}-1.14 \\
(0.23)\end{array}$ & -- & -- & -- & -- & $\begin{array}{l}-0.94 \\
(0.46)\end{array}$ \\
\hline Age & $\begin{array}{c}0.14 \\
(0.06)\end{array}$ & - & -- & -- & -- & $\begin{array}{c}0.25 \\
(0.10)\end{array}$ \\
\hline $\mathrm{Age}^{2} / 10$ & $\begin{array}{l}-0.02 \\
(0.01) \\
\end{array}$ & -- & - & -- & -- & $\begin{array}{l}-0.03 \\
(0.01) \\
\end{array}$ \\
\hline Year dummies? & yes & yes & yes & yes & yes & yes \\
\hline $\begin{array}{l}\text { Industry and firm } \\
\text { size dummies? }\end{array}$ & yes & no & no & no & no & yes \\
\hline $\begin{array}{l}\text { Industry dummies } \\
\text { zero? (p-value) }\end{array}$ & 0.80 & -- & -- & -- & -- & -- \\
\hline Hausman (p-value) & \multicolumn{2}{|c|}{0.00} & -- & - & -- & 0.08 \\
\hline $\mathrm{N}^{*} \mathrm{~T}$ (total obs) & \multicolumn{5}{|c|}{8560} & 2413 \\
\hline N (cross-section) & \multicolumn{5}{|c|}{3001} & 1307 \\
\hline
\end{tabular}

Notes:

a. Workers paid hourly (Arbeiter).

b. Overtime OT=reported actual hours-standard hours if positive, zero otherwise.

c. Undertime UT = standard hours-reported actual hours if positive, zero otherwise.

d. RE refers to random effects, FE to fixed effects: person-job effects.

e. Excluded instrument for IV is published standard hours in industry and month of interview. 
Table 2: Analysis Based on Reported Actual Hours: Services 1984-1989

(Standard Errors in Parentheses)

\begin{tabular}{|c|c|c|c|c|c|c|}
\hline & \multicolumn{3}{|c|}{ Reported actual hours } & \multirow{2}{*}{$\frac{\mathrm{P}(\mathrm{OT}>0)}{\text { FE logit }}$} & \multirow{2}{*}{$\frac{P(U T>0)}{\text { FE logit }}$} & \multirow{2}{*}{$\begin{array}{l}\text { OT } \\
\mathrm{FE}\end{array}$} \\
\hline & RE & FE & FE IV & & & \\
\hline Standard Hours $h_{b}$ & $\begin{array}{c}0.76 \\
(0.14) \\
\end{array}$ & $\begin{array}{r}0.62 \\
(0.21) \\
\end{array}$ & $\begin{array}{c}0.58 \\
(0.72) \\
\end{array}$ & $\begin{array}{l}-0.19 \\
(0.10) \\
\end{array}$ & $\begin{array}{c}0.20 \\
(0.20) \\
\end{array}$ & $\begin{array}{l}-0.39 \\
(0.26) \\
\end{array}$ \\
\hline Apprenticeship? & $\begin{array}{c}0.36 \\
(0.54) \\
\end{array}$ & -- & -- & -- & -- & -- \\
\hline University? & $\begin{array}{l}-1.35 \\
(2.86) \\
\end{array}$ & -- & -- & -- & -- & -- \\
\hline Foreign? & $\begin{array}{l}-0.44 \\
(0.51) \\
\end{array}$ & -- & -- & - & -- & -- \\
\hline Female? & $\begin{array}{l}-2.50 \\
(0.61)\end{array}$ & -- & -- & - & -- & -- \\
\hline Age & $\begin{array}{c}0.03 \\
(0.18)\end{array}$ & -- & -- & -- & -- & -- \\
\hline $\mathrm{Age}^{2} / 10$ & $\begin{array}{l}-0.01 \\
(0.02) \\
\end{array}$ & -- & -- & - & -- & -- \\
\hline Year dummies? & yes & yes & yes & yes & yes & yes \\
\hline $\begin{array}{l}\text { Industry and firm } \\
\text { size dummies? }\end{array}$ & yes & no & no & no & no & no \\
\hline $\begin{array}{l}\text { Industry dummies } \\
\text { zero? (p-value) }\end{array}$ & 0.00 & -- & -- & -- & -- & -- \\
\hline Hausman (p-value) & \multicolumn{2}{|c|}{0.00} & -- & - & -- & 0.04 \\
\hline $\mathrm{N}^{*} \mathrm{~T}$ (total obs) & \multicolumn{5}{|c|}{1893} & 628 \\
\hline $\mathrm{N}$ (cross-section) & \multicolumn{5}{|c|}{855} & 369 \\
\hline
\end{tabular}

Notes:

a. Workers paid hourly (Arbeiter).

b. Overtime OT=reported actual hours-standard hours if positive, zero otherwise.

c. Undertime UT =standard hours-reported actual hours if positive, zero otherwise.

d. RE refers to random effects, FE to fixed effects: person-job effects.

e. Excluded instrument for IV is average response of Arbeiter in that industry and year. 
Table 3: Analysis Based on Reported Actual Hours: The Effect of Firm Size (Standard Errors in Parentheses)

\begin{tabular}{|c|c|c|c|c|c|c|}
\hline & \multicolumn{3}{|c|}{ Manufacturing/Construction } & \multicolumn{3}{|c|}{ Services } \\
\hline & \multicolumn{2}{|c|}{ Actual hours } & \multirow{2}{*}{$\frac{P(O T>0)}{\text { FE logit }}$} & \multicolumn{2}{|c|}{ Actual hours } & \multirow{2}{*}{$\frac{\mathrm{P}(\mathrm{OT}>0)}{\text { FE logit }}$} \\
\hline & RE & $\mathrm{FE}$ & & RE & FE & \\
\hline Standard Hours $h_{8}$ & $\begin{array}{c}0.97 \\
(0.12) \\
\end{array}$ & $\begin{array}{c}0.87 \\
(0.09)\end{array}$ & $\begin{array}{l}-0.23 \\
(0.04)\end{array}$ & $\begin{array}{c}0.89 \\
(0.36) \\
\end{array}$ & $\begin{array}{c}0.68 \\
(0.21)\end{array}$ & $\begin{array}{l}-0.06 \\
(0.10)\end{array}$ \\
\hline$h_{a}{ }^{*}$ Firm $<20$ & $\begin{array}{c}0.02 \\
(0.18) \\
\end{array}$ & $\begin{array}{l}-0.030 \\
(0.021) \\
\end{array}$ & $\begin{array}{l}-0.023 \\
(0.010) \\
\end{array}$ & $\begin{array}{l}-0.10 \\
(0.43)\end{array}$ & $\begin{array}{l}-0.100 \\
(0.053) \\
\end{array}$ & $\begin{array}{l}-1.26 \\
(0.82) \\
\end{array}$ \\
\hline$h_{a} *$ Firm 20-199 & $\begin{array}{l}-0.10 \\
(0.15) \\
\end{array}$ & $\begin{array}{l}-0.029 \\
(0.015) \\
\end{array}$ & $\begin{array}{l}-0.022 \\
(0.008) \\
\end{array}$ & $\begin{array}{l}-0.12 \\
(0.43) \\
\end{array}$ & $\begin{array}{l}-0.102 \\
(0.037) \\
\end{array}$ & $\begin{array}{l}-0.030 \\
(0.025) \\
\end{array}$ \\
\hline$h_{s}{ }^{*}$ Firm 200-1999 & $\begin{array}{c}0.07 \\
(0.16) \\
\end{array}$ & $\begin{array}{l}-0.023 \\
(0.012) \\
\end{array}$ & $\begin{array}{l}-0.019 \\
(0.006) \\
\end{array}$ & $\begin{array}{l}-0.31 \\
(0.47) \\
\end{array}$ & $\begin{array}{l}-0.034 \\
(0.031) \\
\end{array}$ & $\begin{array}{l}-0.041 \\
(0.022)\end{array}$ \\
\hline Year dummies? & yes & yes & yes & yes & yes & yes \\
\hline $\begin{array}{l}\text { Industry, education, } \\
\text { nationality, gender, } \\
\text { firm size? }\end{array}$ & yes & no & no & yes & no & no \\
\hline $\begin{array}{l}\text { Industry dummies } \\
\text { zero? (p-value) }\end{array}$ & 0.81 & -- & -- & 0.00 & -- & - \\
\hline Hausman (p-value) & & & - & & & -- \\
\hline $\mathrm{N}^{*} \mathrm{~T}$ (total obs) & \multicolumn{3}{|c|}{8560} & \multicolumn{3}{|c|}{1893} \\
\hline$N$ (cross-section) & \multicolumn{3}{|c|}{3001} & \multicolumn{3}{|c|}{855} \\
\hline
\end{tabular}

Notes:

a. Workers paid hourly (Arbeiter).

b. Overtime OT=reported actual hours-standard hours if positive, zero otherwise.

c. RE refers to random effects, FE to fixed effects: person-job effects. 
Table 4: Manufacturing and Construction 1986, 1988-9

(Standard Errors in Parentheses)

A. Analysis based on reported actual hours

\begin{tabular}{|c|c|c|c|c|c|}
\hline & \multicolumn{3}{|c|}{ Reported actual hours } & \multirow{2}{*}{$\frac{\mathrm{P}(\mathrm{OT}>0)}{\mathrm{FE} \text { logit }}$} & \multirow{2}{*}{$\frac{\mathrm{OT}}{\mathrm{RE}}$} \\
\hline & $\mathrm{RE}$ & $\mathrm{FE}$ & FE IV & & \\
\hline Standard Hours $h_{s}$ & $\begin{array}{c}0.96 \\
(0.09) \\
\end{array}$ & $\begin{array}{c}0.90 \\
(0.14) \\
\end{array}$ & $\begin{array}{c}1.19 \\
(0.60) \\
\end{array}$ & $\begin{array}{l}-0.22 \\
(0.07) \\
\end{array}$ & $\begin{array}{r}0.16 \\
(0.13) \\
\end{array}$ \\
\hline $\begin{array}{l}\text { Industry dummies } \\
\text { zero? (p-value) }\end{array}$ & 0.51 & -- & -- & -- & -- \\
\hline Hausman (p-value) & \multicolumn{2}{|c|}{0.00} & -- & -- & 0.66 \\
\hline
\end{tabular}

B. Analysis based on monthly overtime $\left(\mathrm{OT}^{\mathrm{M}}\right)$

\begin{tabular}{|c|c|c|c|c|c|}
\hline & \multicolumn{3}{|c|}{ Constructed actual hours } & \multirow{2}{*}{$\frac{\mathrm{P}\left(\mathrm{OT}^{\mathrm{M}}>0\right)}{\mathrm{FE} \text { logit }}$} & \multirow{2}{*}{$\frac{\mathrm{OT}^{\mathrm{M}} / 4.33}{\mathrm{RE}}$} \\
\hline & $\mathrm{RE}$ & $\mathrm{FE}$ & FE IV & & \\
\hline Standard Hours $h_{a}$ & $\begin{array}{c}1.03 \\
(0.04) \\
\end{array}$ & $\begin{array}{c}0.99 \\
(0.05) \\
\end{array}$ & $\begin{array}{r}0.97 \\
(0.28) \\
\end{array}$ & $\begin{array}{c}0.03 \\
(0.06) \\
\end{array}$ & $\begin{array}{c}0.01 \\
(0.09) \\
\end{array}$ \\
\hline $\begin{array}{l}\text { Industry dummies } \\
\text { zero? (p-value) }\end{array}$ & 0.00 & -- & -- & -- & -- \\
\hline Hausman (p-value) & \multicolumn{2}{|c|}{0.13} & -- & -- & 0.73 \\
\hline
\end{tabular}

\begin{tabular}{||l|l|l|l|l|c||}
\hline Year dummies? & yes & yes & yes & yes & yes \\
\hline $\begin{array}{l}\text { Industry, education, } \\
\text { nationality,gender, } \\
\text { firm size? }\end{array}$ & yes & no & no & no & yes \\
\hline N*T (total obs) & & \multicolumn{5}{|c|}{3991} & $1260 / 1265$ \\
\hline N (cross-section) & \multicolumn{3}{|c|}{2080} & $886 / 901$ \\
\hline
\end{tabular}

\section{Notes:}

a. Workers paid hourly (Arbeiter).

b. Overtime OT=reported actual hours-standard hours if positive, zero otherwise.

c. Constructed actual hours $=$ standard hours + reported monthly overtime/4.33.

d. RE refers to random effects, FE to fixed effects: person-job effects.

e. Excluded instrument for IV is published standard hours in industry and month of interview. 
Table 5: Services 1986, 1988-9

(Standard Errors in Parentheses)

A. Analysis based on reported actual hours

\begin{tabular}{|c|c|c|c|c|c|}
\hline & \multicolumn{3}{|c|}{ Reported actual hours } & $\mathrm{P}(\mathrm{OT}>0)$ & OT \\
\hline & RE & FE & FE IV & FE logit & RE \\
\hline Standard Hours $h_{s}$ & $\begin{array}{c}0.68 \\
(0.22)\end{array}$ & $\begin{array}{c}0.83 \\
(0.39)\end{array}$ & $\begin{array}{c}3.60 \\
(1.33)\end{array}$ & $\begin{array}{l}-0.16 \\
(0.24)\end{array}$ & $\begin{array}{c}-0.05 \\
(0.26)\end{array}$ \\
\hline $\begin{array}{l}\text { Industry dummies } \\
\text { zero? (p-value) }\end{array}$ & 0.05 & -- & -- & -- & -- \\
\hline Hausman (p-value) & \multicolumn{2}{|c|}{0.00} & -- & -- & 0.21 \\
\hline
\end{tabular}

B. Analysis based on monthly overtime $\left(\mathrm{OT}^{\mathrm{M}}\right)$

\begin{tabular}{|c|c|c|c|c|c|}
\hline & \multicolumn{3}{|c|}{ Constructed actual hours } & \multirow{2}{*}{$\frac{\mathrm{P}\left(\mathrm{OT}^{\mathrm{M}}>0\right)}{\mathrm{FE} \text { logit }}$} & \multirow{2}{*}{$\frac{\mathrm{OT}^{\mathrm{M}} / 4.33}{\mathrm{RE}}$} \\
\hline & RE & FE & FE IV & & \\
\hline Standard Hours $h_{s}$ & $\begin{array}{c}1.21 \\
(0.09)\end{array}$ & $\begin{array}{c}1.22 \\
(0.13)\end{array}$ & $\begin{array}{c}0.99 \\
(0.46)\end{array}$ & $\begin{array}{c}0.07 \\
(0.06)\end{array}$ & $\begin{array}{c}0.18 \\
(0.28) \\
\end{array}$ \\
\hline $\begin{array}{l}\text { Industry dummies } \\
\text { zero? (p-value) }\end{array}$ & 0.02 & -- & -- & -- & -- \\
\hline Hausman (p-value) & \multicolumn{2}{|c|}{0.20} & -- & -- & 0.35 \\
\hline
\end{tabular}

\begin{tabular}{||l|l|c|c|c|c||}
\hline Year dummies? & yes & yes & yes & yes & yes \\
\hline $\begin{array}{l}\text { Industry,education, } \\
\text { nationality,gender, } \\
\text { firm size? }\end{array}$ & yes & no & no & no & yes \\
\hline$N^{*}$ (total obs) & & \multicolumn{5}{|c|}{849} & $297 / 307$ \\
\hline N (cross-section) & \multicolumn{3}{|c|}{522} & $211 / 228$ \\
\hline
\end{tabular}

Notes:

a. Workers paid hourly (Arbeiter).

b. Overtime OT =reported actual hours-standard hours if positive, zero otherwise.

c. Constructed actual hours $=$ standard hours + reported monthly overtime/4.33.

d. RE refers to random effects, FE to fixed effects: person-job effects.

e. Excluded instrument for IV is average response of Arbeiter in that industry and year. 
Table 6: Wage Regressions 1986, 1988-9; Reported Monthly Overtime (OT ${ }^{\mathrm{M}}$ )

\begin{tabular}{|l|c|c|c|c||}
\cline { 2 - 5 } \multicolumn{1}{c|}{} & \multicolumn{2}{c|}{ Arbeiter (paid hourly) } & \multicolumn{2}{c||}{ Angestellten (salaried) } \\
\cline { 2 - 5 } \multicolumn{1}{c|}{} & Manufacturing & Services & Manufacturing & Services \\
\hline \hline Standard Hours $\mathrm{h}_{\mathrm{a}}$ & $\begin{array}{c}-0.020 \\
(0.003)\end{array}$ & $\begin{array}{c}-0.026 \\
(0.008)\end{array}$ & $\begin{array}{c}-0.029 \\
(0.008)\end{array}$ & $\begin{array}{c}-0.010 \\
(0.007)\end{array}$ \\
\hline $\log \left(\mathrm{h}_{\mathrm{a}}\right)$ & 1 & 1 & 1 & 1 \\
\hline $\mathrm{OT}^{\mathrm{M}} /\left(4.33 * \mathrm{~h}_{\mathrm{a}}\right)$ & 1.25 & 1.25 & 1.25 & 1.25 \\
\hline $\mathrm{UT}^{\mathrm{M}} /\left(4.33 * \mathrm{~h}_{\mathrm{s}}\right)$ & -- & -- & -- & -- \\
\hline Year dummies? & yes & yes & yes & yes \\
\hline Hausman (p-value) & 0.00 & 0.00 & 0.00 & 0.00 \\
\hline $\mathrm{N} * \mathrm{~T}$ (total obs) & 3711 & 788 & 1096 & 1938 \\
\hline $\mathrm{N}$ (cross-section) & 1972 & 487 & 607 & 1125 \\
\hline
\end{tabular}

\section{Notes:}

a. The dependent variable is gross earnings in the previous month on main job.

b. Estimation is by fixed effects: person-job effects.

c. Manufacturing includes construction.

d. If no standard error is reported, the value of the coefficient has been imposed.

e. The Hausman test refers to a random effects specification including all those covariates included in random effects regressions in earlier tables. 
Table 7: Wage Regressions 1984-1989; Overtime Based on Reported Actual Hours (Standard Errors in Parentheses)

\begin{tabular}{|c|c|c|c|c|}
\hline & \multicolumn{2}{|c|}{ Arbeiter (paid hourly) } & \multicolumn{2}{|c|}{ Angestellten (salaried) } \\
\hline & Manufacturing & Services & Manufacturing & Services \\
\hline Standard Hours $h_{s}$ & $\begin{array}{l}-0.018 \\
(0.003) \\
\end{array}$ & $\begin{array}{l}-0.009 \\
(0.007) \\
\end{array}$ & $\begin{array}{r}-0.011 \\
(0.007) \\
\end{array}$ & $\begin{array}{l}-0.018 \\
(0.005) \\
\end{array}$ \\
\hline $\log \left(h_{h}\right)$ & 1 & 1 & 1 & 1 \\
\hline $\mathrm{OT} / \mathrm{h}_{\mathrm{g}}$ & 1.25 & 1.25 & 1.25 & 1.25 \\
\hline $\mathrm{UT} / \mathrm{h}_{\mathrm{s}}$ & -1 & -1 & -1 & -1 \\
\hline Year dummies? & yes & yes & yes & yes \\
\hline Hausman (p-value) & 0.00 & 0.00 & 0.00 & 0.00 \\
\hline $\mathrm{N}^{*} \mathrm{~T}$ (total obs) & 7900 & 1769 & 2210 & 3921 \\
\hline N (cross-section) & 2872 & 811 & 833 & 1557 \\
\hline
\end{tabular}

\section{Notes:}

a. The dependent variable is gross earnings in the previous month on main job.

b. Estimation is by fixed effects: person-job effects.

c. Manufacturing includes construction.

d. Overtime OT = reported actual hours-standard hours if positive, zero otherwise.

e. Undertime UT=standard hours-reported actual hours if positive, zero otherwise.

f. If no standard error is reported, the value of the coefficient has been imposed.

g. The Hausman test refers to a random effects specification including all those covariates included in random effects regressions in earlier tables. 

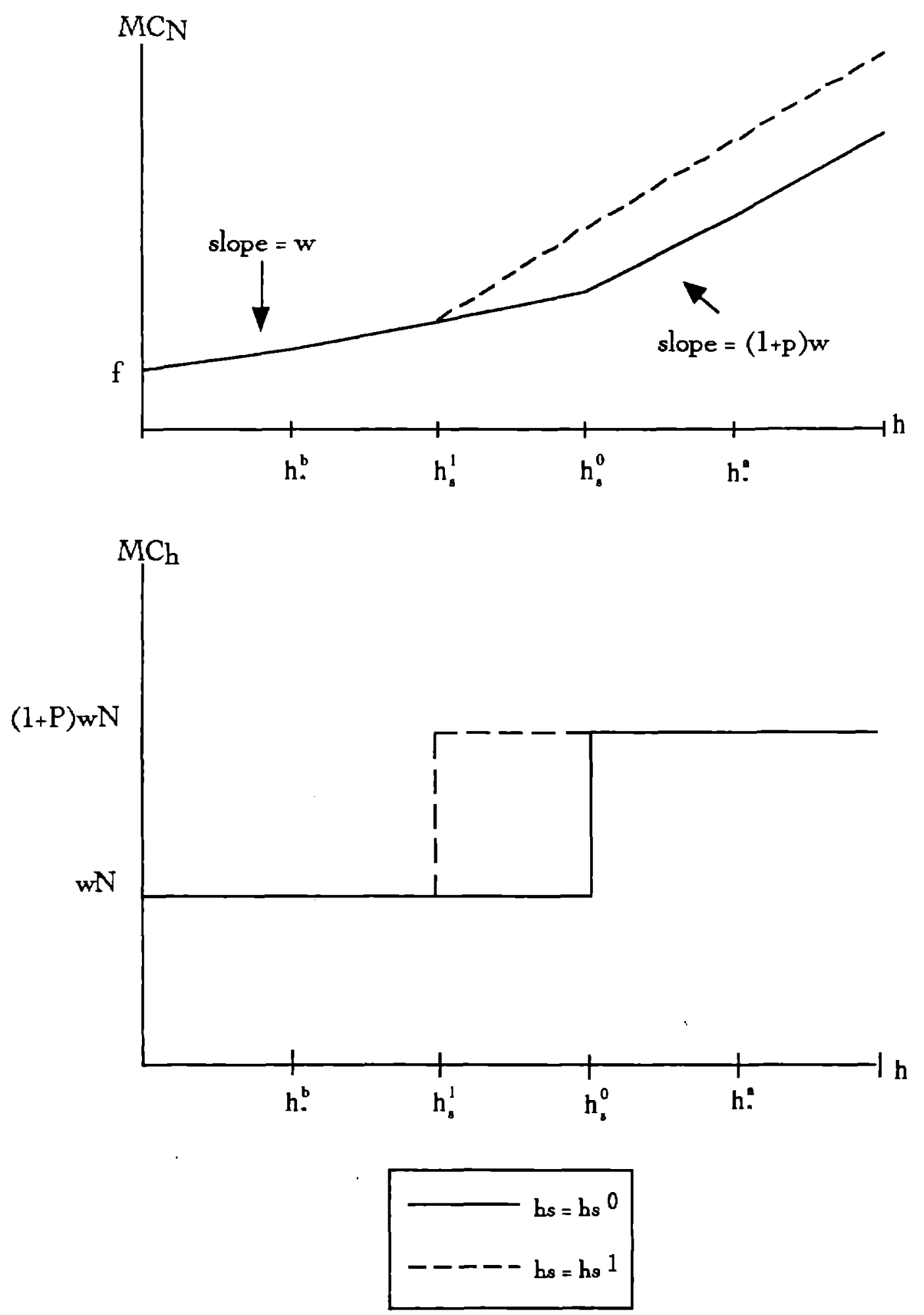

Figure 1a

Substitution Between Workers and Hours: Overtime Premium p 



$$
\begin{array}{r}
-\mathrm{hs}=\mathrm{h} s 0 \\
----\mathrm{h} s=\mathrm{h} s 1
\end{array}
$$

Figure 1b

Substitution Between Workers and Hours: Overtime Premium Increasing With Overtime 




Figure 2: Weekly Overtime for Full Time Workers 

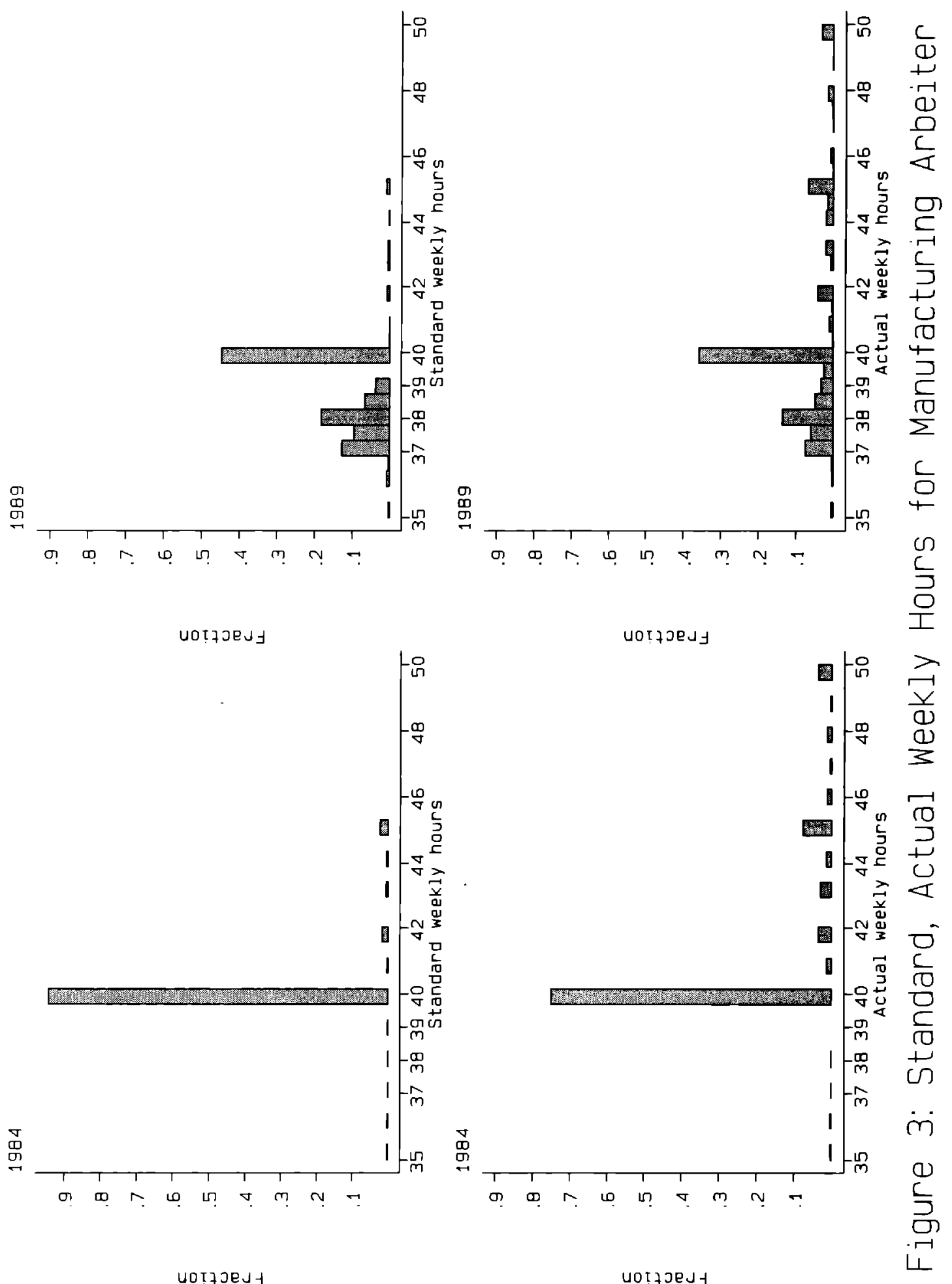

UDI7 JEง

uotzoอง 





NotzJent






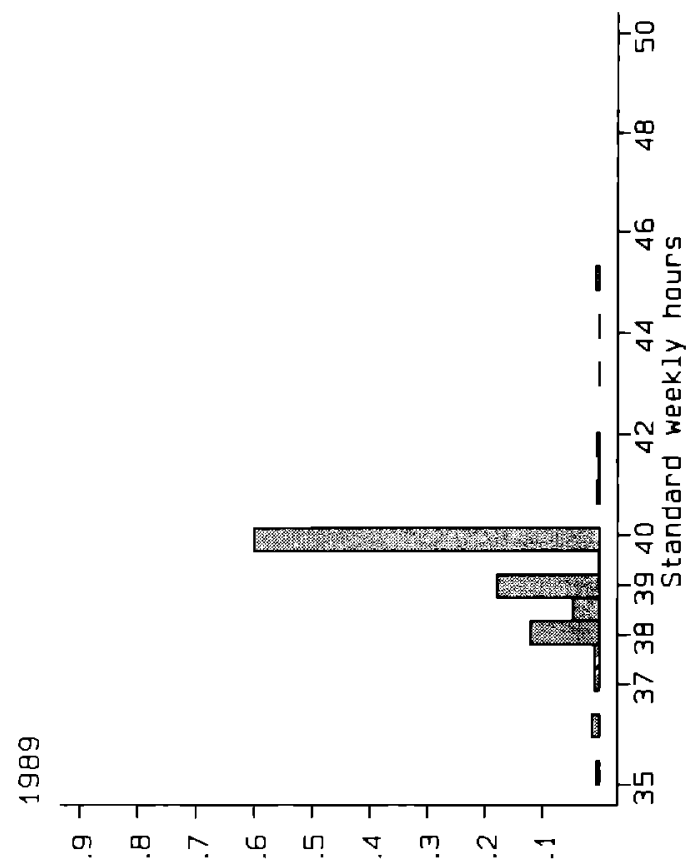

บ0โุวอง



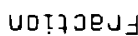

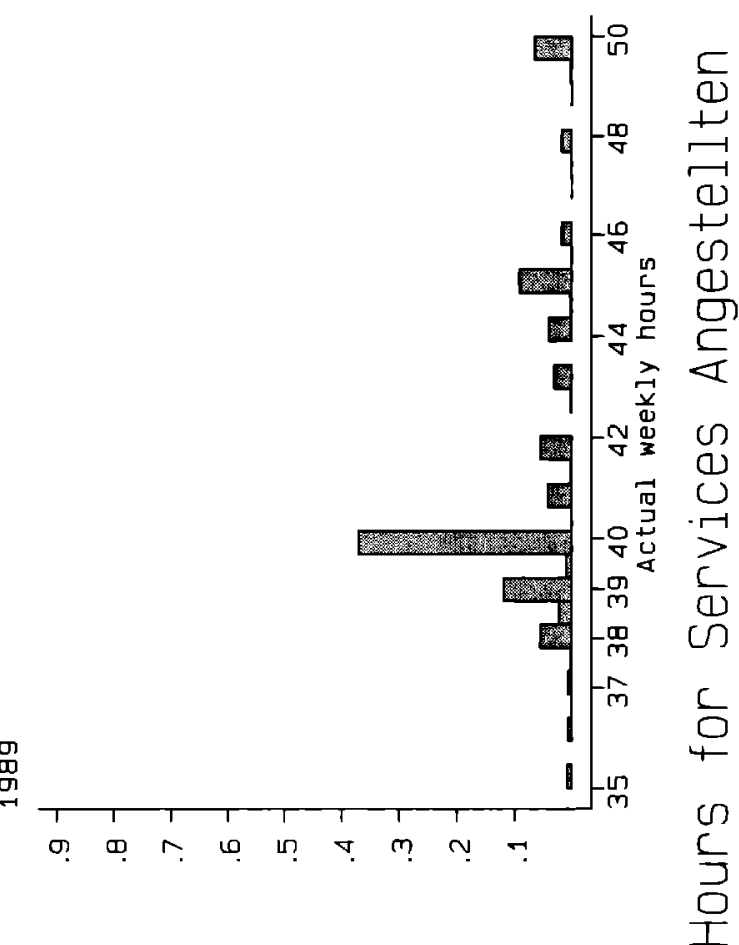

עoז7วอง

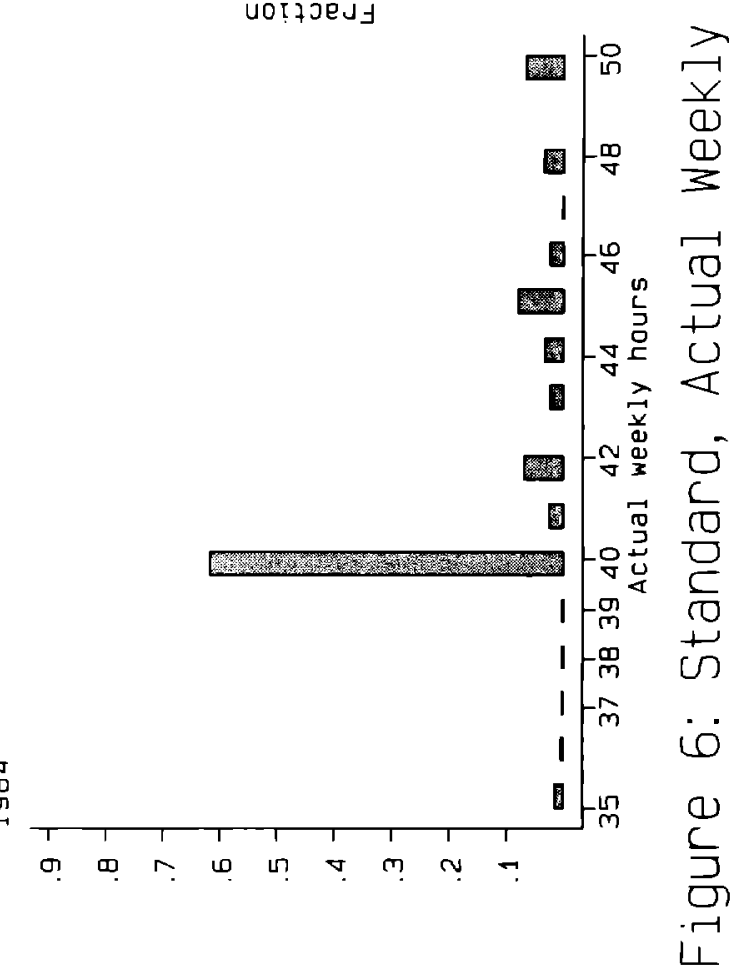

กอเรวองา 



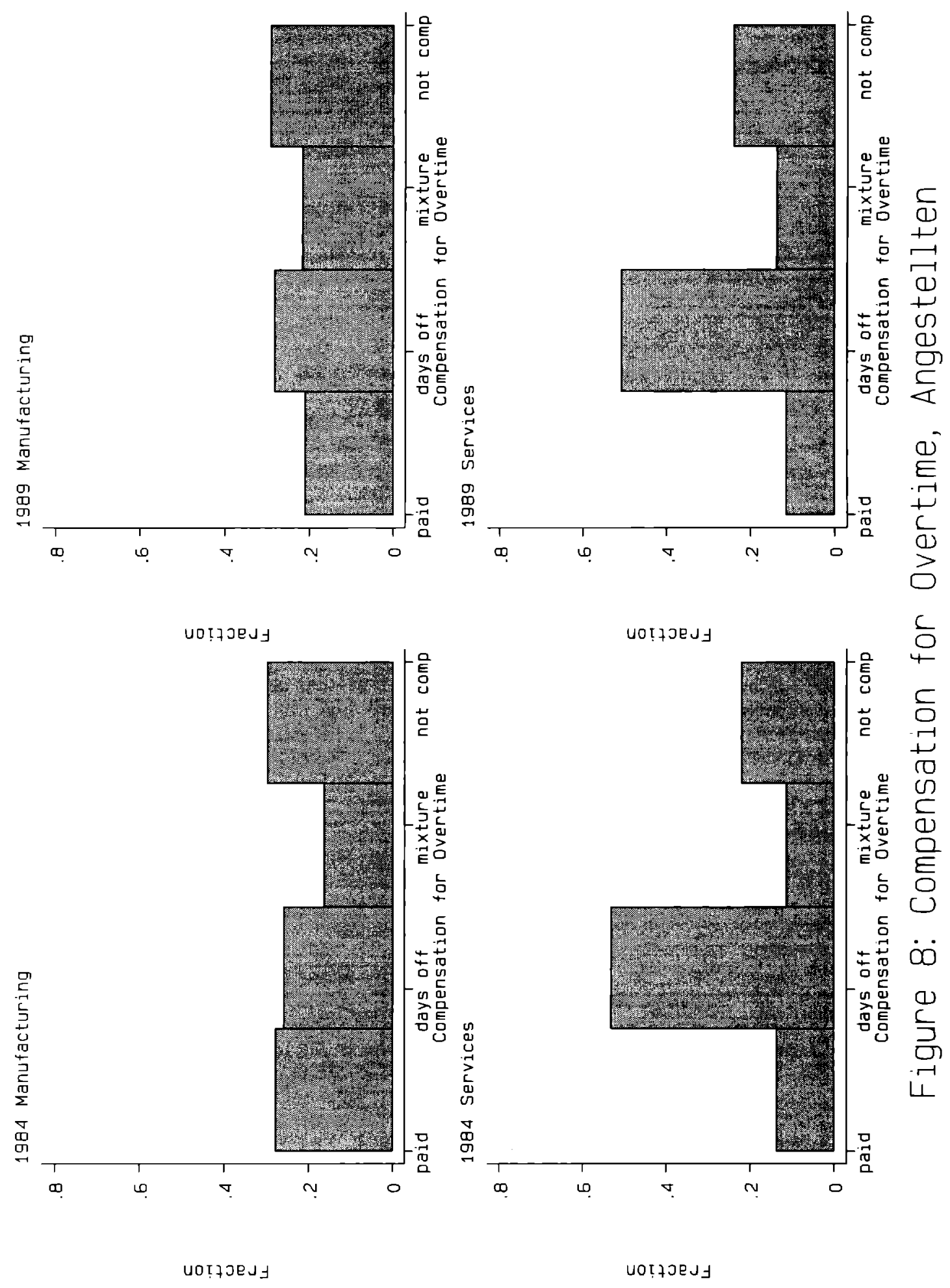



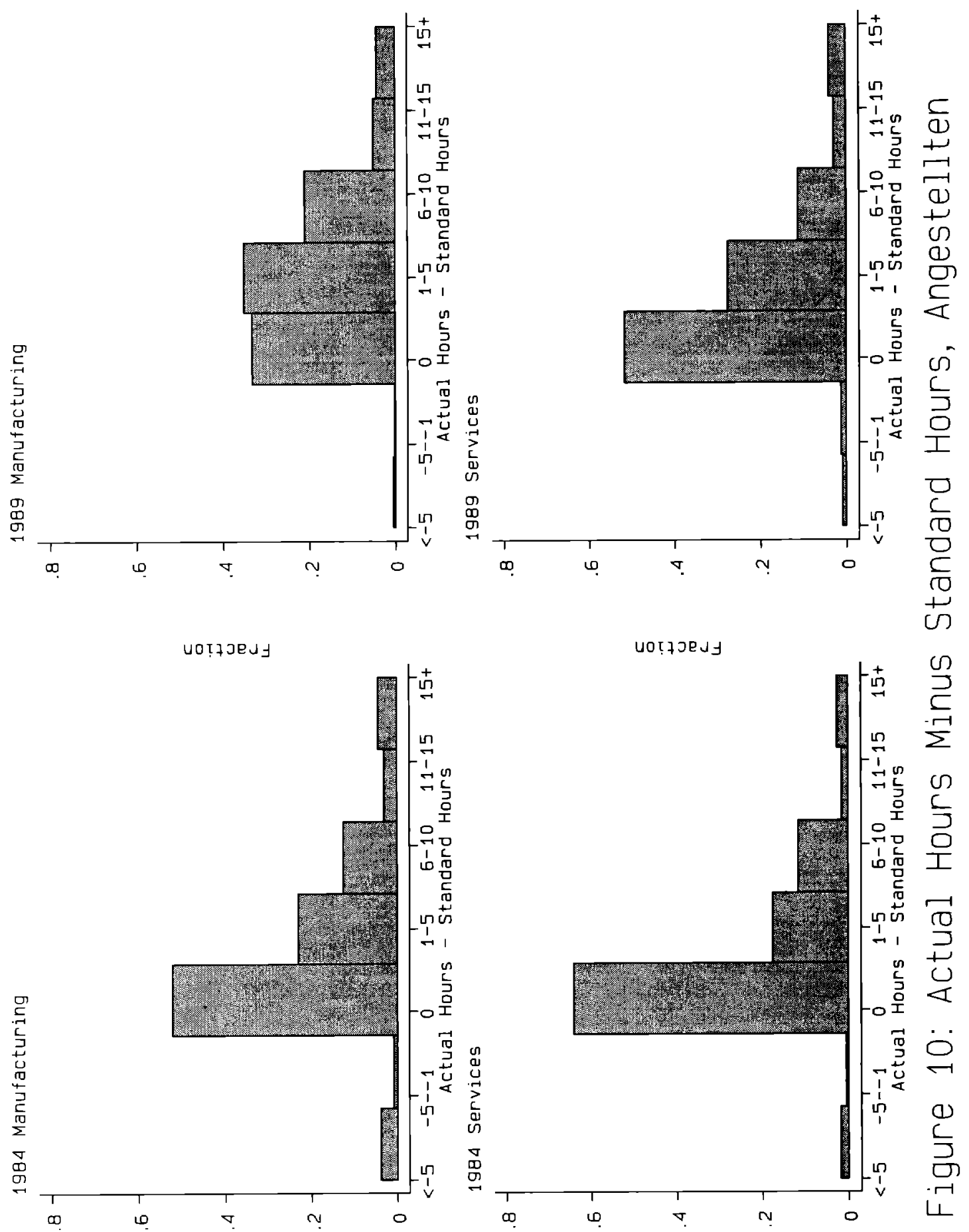

Uотฺวอง

บัโวอยป 

